\title{
Dietary Effects on Very Low-Density Lipoproteins in Type 2 (Non-Insulin-Dependent) Diabetes Mellitus
}

\author{
P. Weisweiler, M. Drosner and P. Schwandt \\ Department of Medicine II, Grosshadern Clinic, University of Munich, Munich, FRG
}

Summary. To evaluate possible influences of dietary intervention on the composition of very low-density lipoproteins (VLDL), ten subjects with Type 2 (non-insulin dependent) diabetes mellitus received a hypocaloric regimen. Fifteen healthy subjects served as controls. Ultracentrifuged VLDL were analysed as cholesterol, triglycerides, apolipoprotein B (apo B), and the soluble apolipoproteins $\mathrm{C}$ and $\mathrm{E}$ (polyacrylamide gel electrophoresis in urea and densitometry) before the study, after 2 weeks and then after 3 months. Compared with the control subjects, the content of cholesterol and apo $E$ in the VLDL was elevated in the diabetic subjects, while the area ratio of apo C-II to apo C-III was lowered. After diet the reduction in VLDL was accompanied by compositional changes: a decrease of the cholesterol/triglyceride ratio and of the apo E/apo $\mathrm{C}$ area ratio. The apo $\mathrm{C}-\mathrm{II} /$ apo $\mathrm{C}-\mathrm{III}_{1}$ area ratio remained unaffected. We conclude that one beneficial effect of therapeutic intervention in diabetes may lie in lowering the level of possibly atherogenic VLDL-components.

Key words: Type 2 diabetes, very low-density lipoproteins, dietary treatment.
Abnormalities in serum lipoproteins are frequent and may contribute to the increased incidence of atherosclerosis in diabetic patients [1]. Most commonly, triglyceride-rich lipoproteins are elevated $[2,3]$. Therapeutic regimens improve hyperglycaemia as well as hypertriglyceridaemia [4]. In very low-density lipoproteins (VLDL), the main density class of triglyceride-rich lipoproteins, apolipoprotein $B$ (apo B) represents the particle concentration [5], the C-apolipoproteins modulate the degradation of lipoproteins [6], and apo $E$ is involved in their receptor binding [7]. Only a few data exist on these apolipoproteins in diabetes mellitus [8, 9], and the effects of diet have not been investigated. We report the influence of a 3-month dietary regimen on VLDL-components in patients with Type 2 (non-insulin dependent) diabetes mellitus.

\section{Patients and Methods}

We studied ten diabetic patients $(27.6 \pm 4.1 \%$ above the ideal weight (mean \pm SD) derived from Metropolitan Life Assurances tables, mean age $41 \pm 16$ years, three males, seven females, mean duration of diabetes $1.1 \pm 1.6$ years). None of the patients had taken drugs known to affect carbohydrate or lipid metabolism (e.g. hormonal therapy, beta blockers, or diuretic drugs). Baseline recorded values for body weight, $10.00 \mathrm{~h}$ blood glucose $(10.49 \pm 2.28 \mathrm{mmol} / \mathrm{l})$, daily uri- nary excretion of glucose $(2.4 \pm 2.9 \mathrm{~g} /$ day), serum cholesterol $(6.00$ $\pm 0.59 \mathrm{mmol} / \mathrm{l})$, and serum triglycerides $(2.61 \pm 0.71 \mathrm{mmol} / \mathrm{l})$ were taken over a 2 -week period in the outpatient clinic.

The subjects were then hospitalized for 2 weeks. After dietary advice by an experienced dietitian, care of the subjects was undertaken in the outpatient clinic for a further 10 weeks. Dietary treatment consisted of 1000 calories daily during the first 2 weeks, then 1500 calories daily for the rest of the study. Thirty percent of energy was derived from protein (vegetable protein 10\%), 30\% from fat, and $40 \%$ from carbohydrates. The ratio between polyunsaturated and saturated fatty acids in the diet was 0.8 and the average cholesterol content $0.15 \mathrm{~g} /$ day and 1000 calories. The intake of simple carbohydrates was rigidly restricted. The patients kept their physical activity at a constant level.

Body weight, blood glucose (estimations at 10.00 and $13.00 \mathrm{~h}$, hexokinase method, Boehringer kit, Mannheim, FRG), and urinary glucose were measured daily during the first 2 weeks, then weekly. Serum lipids and VLDL were determined after a 12 -h fast at the beginning, after 2 weeks, and then after 3 months. Fifteen healthy subjects (same sex distribution, same age range, $6.5 \pm 2.7 \%$ above the ideal weight) on a 3-month isocaloric diet (same food composition as in patients) served as controls.

VLDL were separated from other lipoproteins by tube slicing after ultracentrifugation in a Beckman rotor $40.3(d=1.006 \mathrm{~g} / \mathrm{ml}, 24 \mathrm{~h}$, $105,000 \times \mathrm{g}$ at $4^{\circ} \mathrm{C}$ ). Cholesterol and triglyceride levels in serum and VLDL were measured enzymatically (Boehringer kits, Mannheim, FRG), VLDL-apo B by electroimmunoassay (inter-assay coefficient of variation 2.1\%) [10]. Equal volumes of VLDL and tetramethylurea were then mixed and centrifuged. After determination of the protein content in the supernatant [11], $0.1 \mathrm{mg}$ of soluble VLDL-apolipoproteins were applied to polyacrylamide gel columns (7.5\%), containing $8 \mathrm{~mol} / \mathrm{l}$ urea, and electrophoresis was carried out [12]. The resulting 
Table 1. Blood glucose, serum lipids and VLDL in 10 Type 2 diabetic patients and 15 control subjects before, 2 weeks after and 3 months after a hypocaloric regimen

\begin{tabular}{|c|c|c|c|c|}
\hline \multirow[t]{2}{*}{ Parameters } & \multicolumn{3}{|c|}{ Diabetic patients } & \multirow[t]{2}{*}{ Control subjects } \\
\hline & Prevalues & 2-week diet values & 3-month diet values & \\
\hline \multirow[t]{2}{*}{ Blood glucose $(\mathrm{mmol} / \mathrm{l})$} & $12.93 \pm 2.94$ & $9.94 \pm 2.33^{b}$ & $9.38 \pm 1.55^{b}$ & $5.44 \pm 1.17^{c}$ \\
\hline & $10.49 \pm 2.28$ & $8.83 \pm 2.72^{b}$ & $7.88 \pm 2.22^{b}$ & - \\
\hline Serum cholesterol (mmol/l) & $6.00 \pm 0.59$ & $5.64 \pm 0.52^{\mathrm{a}}$ & $5.72 \pm 0.62$ & $4.68 \pm 1.11^{c}$ \\
\hline Serum triglycerides $(\mathrm{mmol} / 1)$ & $2.61 \pm 0.71$ & $1.95 \pm 0.39^{b}$ & $2.03 \pm 0.56^{\mathrm{a}}$ & $1.12 \pm 0.62^{c}$ \\
\hline VLDL-cholesterol $(\mathrm{mmol} / \mathrm{l})$ & $1.32 \pm 0.41$ & $0.93 \pm 0.26^{\mathrm{b}}$ & $0.96 \pm 0.23^{\mathrm{b}}$ & $0.41 \pm 0.23^{c}$ \\
\hline VLDL-triglycerides $(\mathrm{mmol} / \mathrm{l})$ & $1.94 \pm 0.55$ & $1.48 \pm 0.43^{b}$ & $1.69 \pm 0.47^{\mathrm{a}}$ & $0.80 \pm 0.67^{\circ}$ \\
\hline VLDL-apo B (g/l) & $0.18 \pm 0.05$ & $0.14 \pm 0.06^{\mathrm{b}}$ & $0.12 \pm 0.07^{\mathrm{b}}$ & $0.06 \pm 0.02^{c}$ \\
\hline Soluble VLDL-apolipoproteins (g/1) & $0.32 \pm 0.14$ & $0.23 \pm 0.07^{b}$ & $0.22 \pm 0.06^{\mathrm{b}}$ & $0.13 \pm 0.01^{c}$ \\
\hline Cholesterol/triglyceride ratio in VLDL & $0.69 \pm 0.37$ & $0.62 \pm 0.35^{\mathrm{a}}$ & $0.56 \pm 0.26^{b}$ & $0.51 \pm 0.22^{c}$ \\
\hline
\end{tabular}

Results expressed as mean \pm SD. Wilcoxon rank test (prevalues versus diet values, paired testing: ${ }^{a} p<0.05$, ${ }^{b} p<0.01$; prevalues versus control subjects, unpaired testing: ${ }^{\mathrm{c}} p<0.01$ )

Table 2. Soluble VLDL-apolipoproteins in 10 Type 2 diabetic and 15 control subjects before, 2 weeks after and 3 months after a hypocaloric regimen

\begin{tabular}{|c|c|c|c|c|}
\hline \multirow[t]{2}{*}{ Parameters ( $\%$ dye uptake) } & \multicolumn{3}{|c|}{ Diabetic patients } & \multirow[t]{2}{*}{ Control subjects } \\
\hline & Prevalues & 2-week diet values & 3 -month diet values & \\
\hline Unidentified protein & $5.9 \pm 4.9$ & $6.7 \pm 6.9$ & $5.9 \pm 6.1$ & $6.4 \pm 6.8$ \\
\hline Apo E & $22.4 \pm 10.1$ & $14.4 \pm 6.9^{\mathrm{a}}$ & $16.7 \pm 7.3^{\mathrm{a}}$ & $17.6 \pm 7.0$ \\
\hline C-apolipoproteins & $71.7 \pm 31.3$ & $78.9 \pm 34.8$ & $77.4 \pm 30.5$ & $76.0 \pm 25.2$ \\
\hline Apo C-I & $10.9 \pm 5.1$ & $12.8 \pm 6.9$ & $12.1 \pm 3.9$ & $11.5 \pm 2.2$ \\
\hline Apo C-II & $12.9 \pm 8.3$ & $15.8 \pm 7.9$ & $14.7 \pm 7.1$ & $16.6 \pm 6.0$ \\
\hline Apo C-III & $30.1 \pm 9.1$ & $31.6 \pm 9.5$ & $30.7 \pm 10.1$ & $29.7 \pm 9.5$ \\
\hline Apo C-III 2 & $17.8 \pm 5.6$ & $18.7 \pm 4.6$ & $19.9 \pm 6.1$ & $18.2 \pm 6.2$ \\
\hline Apo E/apo C area ratio & $0.31 \pm 0.09$ & $0.20 \pm 0.10^{\mathrm{a}}$ & $0.21 \pm 0.08^{\mathrm{a}}$ & $0.23 \pm 0.10^{\mathrm{b}}$ \\
\hline Apo C-II/apo C-III ${ }_{1}$ area ratio & $0.43 \pm 0.18$ & $0.49 \pm 0.21$ & $0.48 \pm 0.19$ & $0.56 \pm 0.19^{b}$ \\
\hline
\end{tabular}

Results expressed in mean \pm SD. Wilcoxon rank test (prevalues versus diet values, paired testing: ${ }^{a} p<0.01$; prevalues versus control subjects, unpaired testing: ${ }^{\mathrm{b}} p<0.05$

bands were stained with Amidoschwarz $10 \mathrm{~B}$ and destained in $7 \%$ acetic acid. The dye uptake was determined by a scanner integrator (570 nm, Hirschmann, Munich, FRG). All samples for gel electrophoresis were run within 1 week under identical conditions. Significances were calculated by the Wilcoxon rank test (paired and unpaired testing).

\section{Results}

Compared with the control subjects, the diabetic patients had elevated concentrations of serum lipids and VLDL. With regard to the VLDL-composition, they had an elevated cholesterol/triglyceride ratio and an elevated apo E/apo $\mathrm{C}$ area ratio, but a lowered apo $\mathrm{C}$-II/apo $\mathrm{C}-\mathrm{III}_{1}$ area ratio (Tables 1 and 2). The dietary treatment resulted in a reduction of serum lipid and VLDL-levels and the cholesterol/triglyceride ratio in VLDL. Furthermore, there was a decrease of the apo $\mathrm{E}$ content resulting in a fall of the apo $\mathrm{E} /$ apo $\mathrm{C}$ area ratio after diet. These changes were maintained after the initial period in hospital, i.e. the 3-month values were not significantly different from the 2 -week values. The diet did not influence the distribution of the C-apolipoproteins. The apo C-II/apo C-III 1 area ratio remained low- ered in the diabetic patients. Sex differences in the response of the VLDL-changes to diet were not observed.

The decrease of mean body weight was $4.2 \pm 2.9 \mathrm{~kg}$ after 2 weeks and $10.8 \pm 2.9 \mathrm{~kg}$ after 3 months $(12.9 \pm$ $5.1 \%$ above the ideal weight at the end of the study). The decrease of blood glucose concentrations by diet (Table 1) resulted in a disappearance of glycosuria.

\section{Discussion}

In agreement with the findings of Gabor et al. [9], we found a lowered apo C-II/apo C-III ${ }_{1}$ area ratio in diabetic patients compared with control subjects. Furthermore, our slightly, obese and hypertriglyceridaemic diabetic patients had an elevated cholesterol and apo $\mathrm{E}$ content in VLDL which are assumed to reflect an elevated concentration of remnant particles [5].

Together with the reported increase of intermediatedensity lipoproteins [13] this accumulation of remnant lipoproteins in diabetic patients implies that there are alterations in the catabolic pathway of triglyceride-rich lipoproteins. One explanation may be the altered distribution of apo C in VLDL [9], finally favouring a re- 
duced activity of lipoprotein lipase in uncontrolled diabetes [14]. Another possibility is an altered turnover rate of apo B in diabetes mellitus [8]. Thirdly, changes in high-density lipoproteins (HDL) with a decrease of the $\mathrm{HDL}_{2}$-subfraction in Type 2 diabetes may be responsible for disturbances in the catabolism of triglyceriderich lipoproteins $[13,15,16]$. Comparable alterations of the HDL-subfractions have been reported in obese subjects without diabetes [17].

As demonstrated in our study, a hypocaloric diet not only reduces VLDL-concentrations, but also changes their composition. It cannot be clearly distinguished, whether the improved diabetic control, the improved hypertriglyceridaemia, or the weight loss is the prime factor in influencing the VLDL-components. Nevertheless, the fall of the cholesterol and apo $E$ content in VLDL points at a preferential elimination of remnant particles. Similar changes of the VLDL-composition have been described after a diet poor in cholesterol and high in polyunsaturated fatty acids in normal men [18] and after hormonal substitution in hypothyroid patients [19]. It remains to be established which mechanisms other than the apo $\mathrm{E}$ isoprotein distribution (disturbed in Type III hyperlipoproteinaemia) are responsible for the remnant catabolism. There is some evidence that remnants are easily taken up by tissue cells, causing cholesterol accumulation $[20,21]$ and may be associated with an increased risk of atherosclerosis [22]. One beneficial effect of diet in diabetes may, therefore, lie in lowering the level of possibly atherogenic VLDL.

Acknowledgements. We wish to recognize the valuable technical assistance by Mrs. M. Greiner and Mrs. H. Schlaffke.

\section{References}

1. Garcia MJ, McNamara PM, Gordon T, Kannell WB (1974) Morbidity and mortality in diabetics in the Framingham population. Diabetes 23: 105-111

2. Wilson DE, Brown VW (1978) Lipids and lipoproteins in diabetes mellitus. In: Katzen HM, Mahler RJ (eds) Advances in modern nutrition 2, Part 1. Raven Press, New York, pp 127-186

3. Sosenko JM, Breslow JL, Miettinen OS, Gabbay KH (1980) Hyperglycaemia and plasma lipid levels. A prospective study of young insulin-dependent diabetic patients. N Engl J Med 302: 650-654

4. Albrink MJ (1975) Dietary and drug treatment of hyperlipidaemia in diabetes. Diabetes 23:913-918

5. Eisenberg S (1979) Very low-density lipoprotein metabolism. Prog Biochem Pharmacol 15: 139-165

6. Ganesan D, Bass HB, McConathy WJ, Alaupovic P (1976) Is decreased activity of C-II activated lipoprotein lipase in Type III hyperlipoproteinaemia (broad- $\beta$-disease) a cause or an effect of increased apolipoprotein E levels? Metabolism 25: 1189-1 195
7. Innerarity TL, Mahley RW (1978) Enhanced binding by cultured human fibroblasts of apo E-containing lipoproteins as compared with low-density lipoproteins. Biochemistry 17: 1440-1447

8. Schonfeld G, Birge L, Miller JP, Kessler G, Santiago J (1974) Apoprotein B levels and altered lipoprotein composition in diabetes. Diabetes 23: 827-834

9. Gabor J, Spain M, Kalant N (1980) Composition of serum very low-density and high-density lipoproteins in diabetes. Clin Chem 26: 1261-1265

10. Schwandt P, Weisweiler P (1980) The effect of D-thyroxine on lipoprotein lipids and apolipoproteins in primary Type IIa hyperlipoproteinaemia. Atherosclerosis 35: 301-306

11. Lowry OH, Rosebrough NJ, Farr AL, Randall RJ (1951) Protein measurement with the Folin phenol reagent. J Biol Chem 193: 265-275

12. Kane JP (1973) A rapid electrophoretic technique for identification of subunit species of apoproteins in serum lipoproteins. Anal Biochem 53:350-364

13. Lisch HJ, Sailer S (1981) Lipoprotein patterns in diet, sulphonurea, and insulin-treated diabetics. Diabetologia 20: 118-122

14. Taskinen MR, Nikkilä EA (1979) Lipoprotein lipase activity of adipose tissue and skeletal muscle in insulin-deficient human diabetes. Diabetologia 17:351-356

15. Lopes-Virella MFL, Stone PG, Colwell JA (1977) Serum highdensity lipoproteins in diabetic patients. Diabetologia 13:285-291

16. Taylor KG, Wright AD. Carter TJN, Valente AJ, Betts SA, Matthews KA (1981) High-density lipoprotein cholesterol and apolipoprotein A-I levels at diagnosis in patients with non-insulin dependent diabetes. Diabetologia 20:535-539

17. Schwandt P, Weisweiler P (1981) High-density lipoprotein subfractions after a short-term fast. Horm Metab Res 13: 467-468

18. Weisweiler P, Drosner M, Janetschek P, Schwandt P (1981) Lipidund Apolipoproteingehalt von Lipoproteinen sehr niedriger Dichte (VLDL) unter einer fettmodifizierten Diät. Verh Dtsch Ges Inn Med 87: 976-978

19. Pagnan A, Casam D, Zanetti G, Guarini P, Braggion M (1980) Serum lipids, double pre-beta lipoproteinaemia, and distribution of the apo very low-density lipoprotein (VLDL) peptides in hypothyroid patients before and after substitution therapy. Metabolism 29: 1026-1030

20. Bierman EL, Stein O, Stein Y (1974) Lipoprotein uptake and metabolism by rat aortic smooth muscle cells in tissue culture. Circ Res 35: $136-150$

21. Goldstein JL, Ho YK, Brown MS, Innerarity TL, Mahley RW (1980) Cholesteryl ester accumulation in macrophages resulting from receptor mediated uptake and degradation of hypercholesterolaemia canine $\beta$-very low-density lipoproteins. $\mathbf{J}$ Biol Chem 255: 1839-1848

22. Pagnan A, Havel RJ, Kane JP, Kotite L (1977) Characterization of human very low-density lipoproteins containing two electrophoretic populations: double pre-beta lipoproteinaemia and primary dyslipoproteinaemia. J Lipid Res 18: 613-622

Received: 28 July 1981

and in revised form: 5 March 1982

Dr. Peter Weisweiler

Medizinische Abteilung II

Klinikum Großhadern

Universität München

Marchioninistraße 15

D-8000 München 70, FRG 